\title{
Combination of vasostatin and cyclophosphamide in the therapy of murine melanoma tumors
}

\author{
Joanna Jazowiecka-Rakus, Magdalena Jarosz, Dorota Kozłowska, \\ Aleksander Sochanik and Stanisław Szala ${ }^{\bowtie}$ \\ Department of Molecular Biology, Maria Skłodowska-Curie Memorial Cancer Center and Institute of Oncology, \\ Gliwice, Poland
}

Received: 16 January, 2007; revised: 22 February, 2007; accepted: 14 March, 2007

available on-line: 20 March, 2007

\begin{abstract}
Growth of tumors is strongly dependent upon supply of nutrients and oxygen by de novo formed blood vessels. Inhibiting angiogenesis suppresses growth of primary tumors as well and affects development of metastases. We demonstrate that recombinant MBP/vasostatin fusion protein inhibits proliferation of endothelial cells in vitro. The therapeutic usefulness of such intratumorally delivered recombinant protein was then assessed by investigating its ability to inhibit growth of experimental murine melanomas. In the model of B16-F10 melanoma the MBP/vasostatin construct significantly delayed tumor growth and prolonged survival of treated mice. A combination therapy involving MBP/vasostatin construct and cyclophosphamide was even more effective and led to further inhibition of the tumor growth and extended survival. We show that such combination might be useful in the clinical setting, especially to treat tumors which have already formed microvessel networks.
\end{abstract}

Keywords: antiangiogenic, anticancer, vasostatin, CTX, combination therapy

\section{INTRODUCTION}

The development of both primary and metastatic tumors is dependent on angiogenesis, i.e. formation of new blood capillaries from preexisting vessels (Folkman, 1971). It is widely assumed that, without accompanying angiogenesis, nests of cancer cells cannot exceed $2-3 \mathrm{~mm}^{3}$ in size (Folkman, 1971). The progress of angiogenesis appears to be controlled by an equilibrium of proangiogenic (stimulating) and antiangiogenic (inhibiting) factors. Over a dozen angiogenesis-promoting molecules have been identified, mainly growth factors (e.g., VEGF or bFGF), whereas the inhibitor group includes a number of endogenous proteins (e.g., angiostatin or endostatin). Angiogenesis is either induced or repressed, depending on the equilibrium switch that reflects shifts between both types of factors involved (Folkman, 2003). Ongoing angiogenesis thus requires either increased levels of stimulating factors and/or decreased levels of their natural inhibitors (Hanahan \& Folkman, 1996).

Both angiogenesis-stimulating factors and inhibitors targeting angiogenesis have been used in attempts to gain control over tumor growth. Repressing the formation of tumor blood vessels leads to inhibited growth of primary tumors as well as of metastases (Folkman, 2003).

More than 300 angiogenesis-inhibiting molecules have been discovered so far. About sixty of them have been pre-clinically verified with some reaching second or even third phase of clinical as-

\footnotetext{
$\square^{\square}$ Corresponding author: Stanisław Szala, Department of Molecular Biology, Maria Skłodowska-Curie Memorial Cancer Center and Institute of Oncology, Wybrzeże Armii Krajowej 15, 44-101 Gliwice, Poland; tel.: (48 32) 278 9879; fax: (48 32) 279 9846; e-mail sszala@io.gliwice.pl

Abbreviations: BAEC, bovine aortic endothelial cells; bFGF, basic fibroblast growth factor; CB, column buffer; CTX, cyclophosphamide; DAB, 3,3'-diaminebenzidine; FB, formulation buffer; FBS, fetal bovine serum; MTT, monotetrazolium; MBP, maltose binding protein; IPTG, isopropyl $\beta$-D-thiogalactoside; LB, Luria-Bertani broth; PBS $^{-}$, phosphate-buffered saline without $\mathrm{Mg}^{2+}$ and $\mathrm{Ca}^{2+}$; VEGF, vascular endothelial growth factor; TBS, Tris-buffered saline; TBST, TBS supplemented with Tween 20.
} 
sessment trials (Ribatti \& Vacca, 2005). The tested compounds include VEGF inhibitors, VEGF receptor antagonists, extracellular matrix metalloprotease inhibitors, cytokines, endogenous inhibitors of angiogenesis, integrin antagonists, inhibitors of endothelial cell activation, and angiozymes (Papetti \& Herman, 2002; Cao, 2004; Nyberg et al., 2005). Over twenty antiangiogenic agents are of endogenous origin. They are actually proteolytic fragments of larger proteins (Scappaticci, 2002). Some of the latter originate from extracellular matrix basement membrane, such as collagen XVIII (from which endostatin has been obtained). Other parent proteins are components of the blood clotting system, e.g. thrombospondin, plasminogen or coagulation inhibitor antithrombin III (O'Reilly et al., 1999). Formation of angiogenesis inhibitors from larger proteins may be promoted by tumors themselves through secretion or activation of suitable proteases (Cao, 2004). Antiangiogenic activity was reported for angiostatin (Wu et al., 1997; Sim et al., 1997), endostatin (O'Reilly et al., 1997), antithrombin III (O'Reilly et al., 1999), metalloprotease 2 fragment (PEX) (Brooks et al., 1998), platelet factor 4 fragment (PF-4) (Gupta et al., 1995), canstatin (Kamphaus et al., 2000) and vasostatin (Pike et al., 1998).

Vasostatin, the evolutionarily-conserved Nterminal domain of calreticulin inclusive of amino acids $1-180$ is an about $24 \mathrm{kDa}$ strongly folded globular protein formed by eight antiparallel $\beta$-strands (Pike et al., 1998; Michalak, 1999, Wu et al., 2005). Vasostatin binds $\mathrm{Zn}^{2+}$ ions (Michalak et al., 1999) and is capable of interacting with other proteins (e.g., glucocorticoid receptors, Erp57 or $\alpha$-integrin subunit) (Michalak et al., 1992; Atreya et al., 1995).

Interest in vasostatin as a clinically useful angiogenesis inhibitor has continued owing to its widely reported antiangiogenic properties (e.g., Pike et al., 1998; 1999; Yao et al., 2000; 2002a; Wu et al., 2005). The protein inhibits in vitro proliferation of endothelial cells stimulated by fibroblast growth factor (bFGF) or vascular endothelial growth factor (VEGF) (Pike et al., 1998; Wu et al., 2005) and inhibits angiogenesis in vivo (Pike et al., 1998). Recombinant vasostatin was found to inhibit angiogenesis induced by bFGF in rat cornea (Wu et al., 2005). In vitro studies demonstrated vasostatin-mediated inhibition of endothelial cells' adhesion to laminins (Yao et al., 2002b).

In combination with IL-12 or interferon-induced protein 10, vasostatin inhibits growth of Burkitt lymphoma and murine colon cancer (Yao et al., 2000; 2002a).

Our previous investigation concerned the benefits of gene therapy based on the use of a vasostatin gene construct (Jazowiecka-Rakus et al., 2006). However, in terms of therapeutic agent dose flex- ibility, the protein approach is certainly superior to gene therapy. The study presented herein sought to demonstrate the therapeutic advantage of a composite therapy involving administration of recombinant vasostatin protein and a well-known chemotherapeutic, cyclophosphamide.

\section{MATERIALS AND METHODS}

Vasostatin gene cloning. In order to clone the vasostatin gene, the pCARL plasmid-containing calreticulin sequence (obtained from Dr. M. Michalak, University of Alberta, Edmonton, AB, Canada), was used as a template. The following primers were used: (+) 5' aaaaaggatccgagccegccgtctacttc $3^{\prime}$ and $(-) 5^{\prime}$ aaaaaaagcttcattccaaggagccggactc $3^{\prime}$. The underlined sequences denote the BamHI restriction site in the $(+)$ primer and the HindIII restriction site in the $(-)$ starter. The sequence in bold denotes the termination codon (TGA).

The primer sequences were designed using Primer 3Input software (http://www-genome.wi.mit. edu/cgi-bin/primer/primer3_www.cgi) based on the calreticulin cDNA sequence obtained from the GenBank database (GI: 5921996).

The amplified product was cloned into pMalc2x, a bacterial expression vector (New England, Biolabs) using the malE gene reading frame. This gene encodes a maltose binding protein (MBP) which has a strong affinity for maltose. The pMal-c2x plasmid contains a deletion of the malE signal sequence, allowing this protein to remain in the cytoplasm.

Isolation and purification of recombinant proteins. pMal-c2x/vasostatin and pMal-c2x (control) plasmids were introduced into Escherichia coli TB1 strain. The bacteria were cultured at $37^{\circ} \mathrm{C}$, with intensive shaking, in LB supplemented with $0.2 \%$ dextrose and $100 \mu \mathrm{g} / \mathrm{ml}$ ampicillin, until $\mathrm{OD}_{600}$ about 0.5 . After about $2 \frac{1}{2} \mathrm{~h}$ IPTG was added (final concentration $0.3 \mathrm{mM}$ ). Following a $3-\mathrm{h}$ induction, the cultures were centrifuged for $20 \mathrm{~min} / 6000 \mathrm{rpm}$. The supernatant was discarded and the pellet placed on ice and resuspended in CB buffer $(200 \mathrm{mM} \mathrm{NaCl}$, $1 \mathrm{mM}$ EDTA, $20 \mathrm{mM}$ Tris/ $\mathrm{HCl}, \mathrm{pH} 7.4)$ ) at $10 \mathrm{ml}$ of buffer per $1 \mathrm{~g}$ of pellet. Bacterial lysates were sonicated using twelve 10-s impulses of medium amplitude (Branson sonifier). Then, the lysates were centrifuged for $30 \mathrm{~min}$ at $4^{\circ} \mathrm{C} / 9000 \mathrm{rpm}$ and the supernatant (containing soluble protein fraction) was collected.

The $\mathrm{MBP} /$ vasostatin fusion protein was affinity-chromatography purified using an XK 16/20 column (Amersham, Biosciences) with a 15-ml amylose resin bed (New England, Biolabs). The column was first prewashed with eight volumes of $\mathrm{CB}$ buffer and then the clarified supernatant fraction of solu- 
ble proteins $(2.5 \mu \mathrm{g} / \mu \mathrm{l})$ was loaded on top of the column. Fractions containing unbound proteins were eluted with 12 vol. of $\mathrm{CB}$ buffer whereas the purified $\mathrm{MBP} /$ vasostatin was eluted using $\mathrm{CB}$ buffer supplemented with $10 \mathrm{mM}$ maltose. Protein concentration in the eluate was determined using Bradford assay. The eluate was then dialyzed $\left(18-20 \mathrm{~h}\right.$ at $4^{\circ} \mathrm{C}$, 15000 MWCO Spectrum bags) against 1.51 (triple exchange) of buffer ( $25 \mathrm{mM} \mathrm{NaCl}, 20 \mathrm{mM}$ Tris/HCl, $\mathrm{pH}$ 8.0). The dialysate was further purified on a Source Q-type ion-exchange chromatography column (Amersham Biosciences) using $20 \mathrm{mM}$ Tris/HCl ( $\mathrm{pH}$ 8.0) buffer. The protein was eluted from the column using 18-ml aliquots of $20 \mathrm{mM}$ Tris/ $/ \mathrm{HCl}(\mathrm{pH}$ 8.0) with an increasing $\mathrm{NaCl}$ gradient (25-400 mM). Based on protein quantitation and analyses of polyacrylamide gel separations, the collected fractions were concentrated down to $1 \mathrm{ml}$ using Ultrafree-4 devices (10000 MWCO for MBP or 30000 MWCO for $\mathrm{MBP} /$ vasostatin; Millipore).

The MBP/vasostatin fusion protein was further purified from endotoxins on agarose bed columns containing immobilized polymyxin B (Detoxi-Gel, Pierce Biotechnology). Before loading protein preparations, the column was first prewashed with 5 vol. ( $5 \mathrm{ml}$ ) of $1 \%$ sodium deoxycholate, 5 vol. of endotoxin-free water and 5 vol. of buffer $(0.1 \mathrm{M} \mathrm{NaCl}, 20 \mathrm{mM}$ Tris/HCl, $\mathrm{pH}$ 7.5). Purified proteins were eluted using the same buffer. Eluates containing the highest concentrations of the $\mathrm{MBP} /$ vasostatin fusion protein or MBP were collected. In order to maximize endotoxin elimination, the clean-up procedure was repeated twice. Endotoxin content in the final protein preparations was determined using a Limulus Amebocyte Lysate QCL-1000 kit (Cambrex).

Immunohistochemical identification of vasostatin (Western blot). To identify MBP/vasostatin we used a polyclonal rabbit antibody recognizing MBP (New England, Biolabs) or a polyclonal goat antibody recognizing calreticulin (Santa Cruz) as well as anti-rabbit or anti-goat immunoglobulins (Vector).

Protein preparations were first separated electrophoretically on polyacrylamide gels and electrotransferred $\left(4^{\circ} \mathrm{C}, 90 \mathrm{~min}, 300 \mathrm{~mA}\right)$ onto nitrocellulose filters (Schleicher \& Schuell). The filters were then rinsed (1 $\mathrm{h}$ at room temp.) with Tris-buffered saline (TBS) containing $3 \%$ milk, placed in primary antibody solution (rabbit IgG recognizing MBP or goat IgG recognizing calreticulin, cross-reactive with vasostatin) in TBS with $3 \%$ milk and incubated overnight at $4{ }^{\circ} \mathrm{C}$. The filters were subsequently washed four times (5 min each) in TBST (TBS supplemented with $0.1 \%$ Tween-20), once in TBS and then placed in the solution of a second antibody (recognizing either rabbit IgG or goat IgG, and biotin-conjugated) in TBS with 1\% milk and incubated for $1.5 \mathrm{~h}$ at room temp. The filters were again washed for $5 \mathrm{~min}$ in TBST (four times), once in TBS and were further incubated for $1 \mathrm{~h}$ at room temp. with diluted (1:1000) streptavidin-biotinylated horseradish peroxidase complex (Amersham Biosciences). Following a TBS wash, the filters were incubated for about $1 \mathrm{~min}$ in a peroxidase substrate solution containing $0.2 \% 3,3$ diaminebenzidine (DAB), $0.5 \mathrm{M}$ Tris/ $\mathrm{HCl}(\mathrm{pH} 7.4)$ and $0.3 \% \mathrm{H}_{2} \mathrm{O}_{2}$. After bands had appeared the filters were washed in deionized water.

Influence of $\mathrm{MBP} /$ vasostatin on endothelial cells growth (MTT test). Bovine aortic endothelial cells (BAEC) were seeded at $4 \times 10^{3}$ cells/well in a 96-well plate in $100 \mu \mathrm{l}$ RPMI supplemented with $10 \%$ fetal bovine serum (FBS). After 2-h incubation at $37^{\circ} \mathrm{C}$, the medium was replaced with $75 \mu \mathrm{RPMI}$ containing 10\% FBS and MBP (control) or MBP/vasostatin. Three protein concentrations were used $(0.1,1$ and $10 \mu \mathrm{g} / \mathrm{ml})$, and experiments were done in triplicate. After 1-h incubation, $75 \mu \mathrm{l} \mathrm{bFGF} \mathrm{(20} \mathrm{ng/}$ $\mathrm{ml}$ ) diluted in RPMI with 10\% FBS was added to the wells and incubation was continued for $24 \mathrm{~h}$ at $37^{\circ} \mathrm{C}$. At the end of the incubation, medium was removed from the wells and $100 \mu \mathrm{l}$ of MTT $(0.5 \mathrm{mg}$ MTT/ $1 \mathrm{ml}$ $\mathrm{PBS}^{-}$) solution was added. Plates were further incubated for $3 \mathrm{~h}$ at $37^{\circ} \mathrm{C}$. In order to dissolve formazan formed, an equal volume of $0.04 \mathrm{~N} \mathrm{HCl}$ in isopropanol was added to the MTT solution. The absorbance of the samples was measured at $570 \mathrm{~nm}$ using an ELISA EL 800 reader (BioTek Instruments). The percentage of live cells was estimated as:

$\left(\mathrm{A}_{\text {sample }}-\mathrm{A}_{\text {background }} / \mathrm{A}_{\text {control }}-\mathrm{A}_{\text {background }}\right) \times 100 \%$.

Animals. C57BL/6 mice used throughout the study were from an on-site Animal Facility. The experiments were approved by the Ethics Committee at the Medical University in Warsaw.

In vivo test of angiogenesis inhibition. Inhibition of angiogenesis by the recombinant protein was carried out according to Chen et al. (1999) using 4-week-old C57BL6 female mice. Briefly, animals were anesthetized with $200 \mu \mathrm{l} 2.5 \%$ avertin (about $15 \mu \mathrm{l} / \mathrm{g}$ body mass) and $300 \mu \mathrm{l}$ of Matrigel (Becton Dickinson) infused with fibroblast growth factor (bFGF) and the recombinant $\mathrm{MBP} /$ vasostatin protein $(50 \mu \mathrm{g} / \mathrm{ml})$ was implanted intradermally 1 $\mathrm{cm}$ below the sternum. After 7 days the gel was removed, placed in Drabkin's solution and incubated for $6 \mathrm{~h}$ at room temp. with intermittent mixing. The samples were then centrifuged for $5 \mathrm{~min} / 2500 \mathrm{rpm}$ Supernatant was collected and absorbance measured at $540 \mathrm{~nm}$. The hemoglobin concentration $(\mathrm{g} / \mathrm{dl})$ was calculated as:

$$
13.8 \times\left(\mathrm{A}_{\text {sample }}-\mathrm{A}_{\text {background }} / \mathrm{A}_{\text {standard }}-\mathrm{A}_{\text {background }}\right)
$$

where 13.8 denotes the concentration of the hemoglobin standard used. 
Therapeutic experiments. Six- to eight-weekold mice were inoculated intradermally (left dorsal side) with $2 \times 10^{5}$ B16(F10) melanoma cells in $100 \mu \mathrm{l}$ PBS $^{-}$. Protein aliquots were administered intratumorally, starting on the 5th or 6th day from inoculation. The amount of injected MBP was $40 \mu \mathrm{g} / \mathrm{animal}$ per $100 \mu \mathrm{l}$ FB solution (formulation buffer consisted of sterile saline solution containing $5 \%$ human albumin and $0.5 \%$ mannitol) whereas that of $\mathrm{MBP} /$ vasostatin was 1-100 $\mu \mathrm{g}$ in $100 \mu \mathrm{l} \mathrm{FB}$ (see Discussion).

Cyclophosphamide (170 mg/kg body mass) was injected intraperitoneally starting on the 6th or 7th day of experiment (4 administrations every 6 days were given). For details see Mitrus et al. (2006).

Tumors were measured every 2-3 days using calipers and their volume calculated as in O'Reilly et al. (1997):

$\mathrm{V}=(\text { tumor width })^{2} \times($ tumor length $) \times 0.52$.

Statistics. Results were compared using a non-parametric Mann-Whitney $U$-test. Animal survival (Kaplan-Meier plot) was analyzed using logrank test. Intergroup differences were considered as statistically significant at $P<0.05$. Calculations were done using Statistica 5.0 software.

\section{RESULTS}

\section{Cloning of vasostatin gene}

A 540-bp DNA fragment encoding human vasostatin was obtained using PCR. The amplified product was cloned into a bacterial expression vec- tor pMal-c2x (New England, Biolabs) within the reading frame of the malE gene. The fusion gene (combining malE and vasostatin coding sequence in the pMal-c2x/vasostatin plasmid) was sequenced. The obtained malE sequence was compared to data supplied by New England Biolabs, whereas the vasostatin sequence was compared to that appearing in the GenBank database (GI: 5921996).

\section{Isolation and purification of proteins}

The $\mathrm{MBP} /$ vasostatin fusion protein was isolated from cultures of bacteria harboring the pMal-c2x/vasostatin plasmid construct (Fig. 1A). Yield of the recombinant fusion protein reached $30-50 \mathrm{mg}$ of protein/liter of bacterial culture. MBP protein (control) was obtained (from pMal-c2x plasmid) and purified as described (Fig. 1B). The MBP protein (about $51 \mathrm{kDa}$ ) carries additionally the $\alpha$-fragment of $\beta$-galactosidase whereas MBP forming part of the $\mathrm{MBP} /$ vasostatin fusion protein does not include the $\alpha$-fragment of $\beta$-galactosidase and therefrore its mass is lower $(42 \mathrm{kDa})$. Insertion of the vasostatin gene into the pMal-c2x vector inhibits expression of the $L a c Z$ gene encoding the $\alpha$-fragment of $\beta$-galactosidase. Translation is terminated at the stop codon inserted into the vasostatin sequence using the (-) starter (see Materials and Methods).The whole $\mathrm{MBP} /$ vasostatin fusion protein has a molecular mass of $66 \mathrm{kDa}$.

The proteins were identified using Western blotting. Polyclonal antibodies recognizing either MBP (Fig. 2A) or (to identify vasostatin) calreticulin (Fig. 2B) were used. The mass (66 kDa) of the identified protein corresponded to that of the MBP/vasostatin fusion protein.
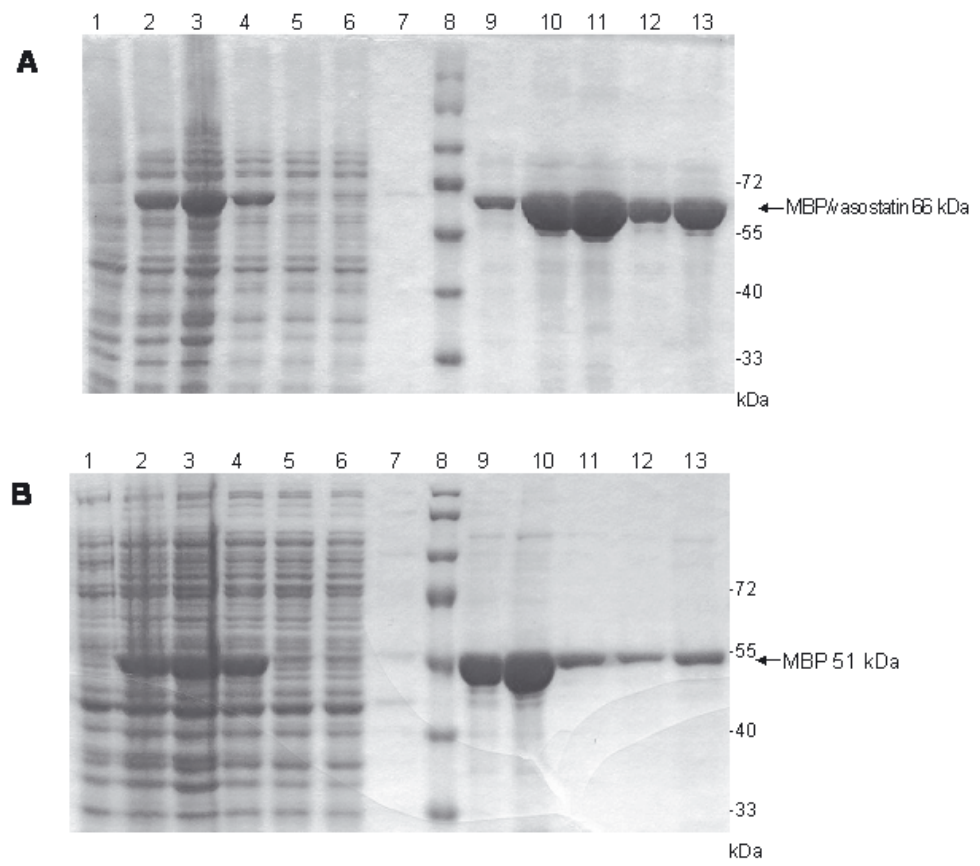

Figure 1. Electrophoretic separation of proteins following purification on amylose bed.

Proteins were separated using 10\% polyacrylamide gel. A. MBP/vasostatin. B. MBP. Total protein before induction (lane 1). Fraction $3 \mathrm{~h}$ after IPTG induction (0.3 mM) (lane 2). Insoluble fraction (lane 3). Soluble fraction (lane 4). Proteins not bound to the bed (lane 5). First wash (fraction 6). Next washes (lane 7). Protein eluates (lanes 9-13). Prestained Protein Ladder size standard (Fermentas) (lane 8). 

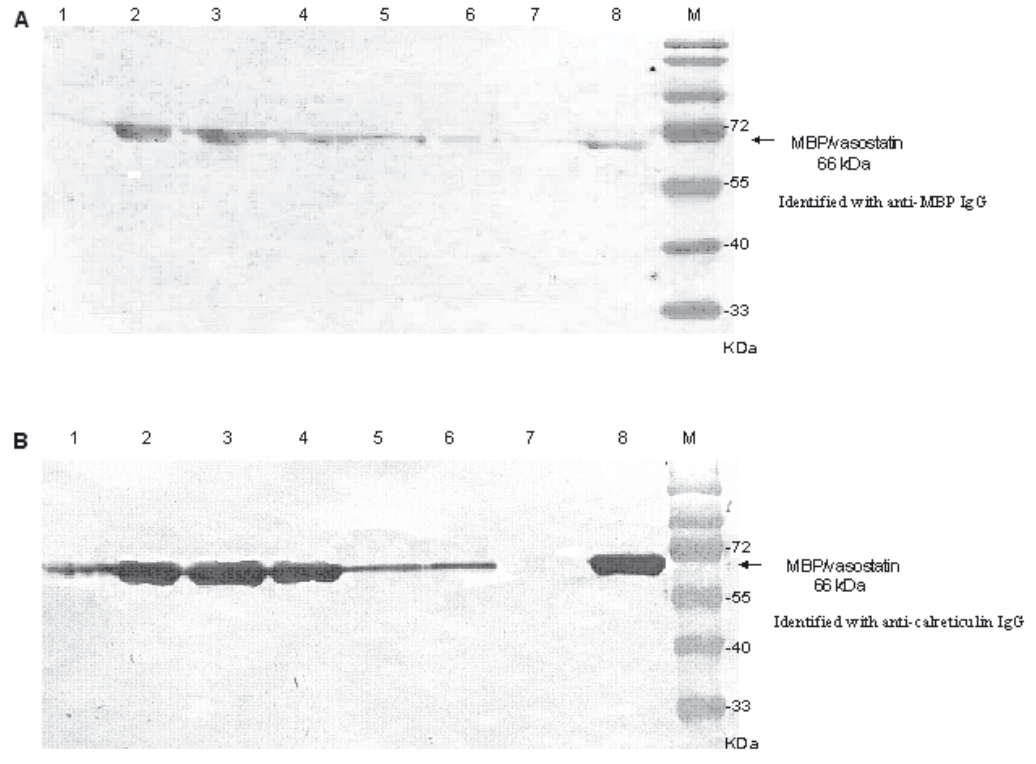

Figure 2. Identification of $\mathrm{MBP} /$ vasostatin fusion protein (Western blot).

Proteins separated on $10 \%$ (A) or $12 \%$ (B) polyacrylamide gel were transferred onto nitrocellulose filter and placed in a solution of MBP-recognizing rabbit antibodies (A) or of goat antibodies recognizing vasostatin (B). The filters were incubated with anti-rabbit (A) or anti-goat (B) immunoglobulin conjugated with biotin and a complex of streptavidin and biotinylated horseradish peroxidase. In order to visualize immunocomplexes the filters were placed in a solution of DAB, a peroxidase substrate. Total protein before induction (lane 1). Fraction $3 \mathrm{~h}$ after IPTG induction (0.3 $\mathrm{mM})$ (lane 2). Insoluble fraction (lane 3). Soluble fraction (lane 4). Proteins not bound to the bed (lane 5). First wash (fraction 6). Next washes (lane 7). Protein eluate (lane 8). Prestained Protein Ladder size standard (Fermentas) (lane M).
The endotoxin level of the purified proteins used subsequently for in vitro and in vivo experiments was less than $<0.1 \mathrm{EU} / \mu \mathrm{g}$ protein.

\section{Determination of the antiangiogenic properties of the $\mathrm{MBP} /$ vasostatin fusion protein}

In order to determine the effect of the fusion protein on the proliferation of endothelial cells in vitro, the MTT test was performed. The MBP/vasostatin fusion protein inhibited proliferation of endothelial cells (BAEC) stimulated by fibroblast growth factor $(46 \%$ at $10 \mu \mathrm{g} / \mathrm{ml}, 37 \%$ at $1 \mu \mathrm{g} / \mathrm{ml}$ and $33 \%$ at $0.1 \mu \mathrm{g} /$ $\mathrm{ml}$ ). MBP used as a control produced no inhibition of BAEC proliferation (Fig. 3).

An angiogenesis-inhibition test using Matrigel was performed to determine the hemoglobin content in intradermally implanted gel plugs supplemented with bFGF and the recombinant proteins. The test represents an indirect functional measure of the density of vessels formed within the Matrigel plug. A decreased hemoglobin concentration reflects inhibited angiogenesis in vivo. The test showed that the examined fusion protein inhibited (by about 48\%) the formation of new vessels within Matrigel. MBP did not affect the angiogenesis (Fig. 4).

\section{$\mathrm{MBP} /$ vasostatin-mediated in vivo therapy of mice bearing B16(F10) tumors}

In subsequent therapeutic experiments a dose of $\mathrm{MBP} /$ vasostatin fusion protein was established that retarded the growth of experimental tumors by at least $80 \%$. The vasostatin construct was administered to mice daily, starting on the 6th day from in- oculation, and continuing for 11 days. Under these circumstances the minimum dose that resulted in so defined tumor growth inhibition was established as $60 \mu \mathrm{g}$ of $\mathrm{MBP} /$ vasostatin per animal and such amounts were used in further studies (Fig. 5).

In a subsequent experiment animals were administered with $60 \mu \mathrm{g}$ of the fusion protein $/ 100 \mu \mathrm{l}$ $\mathrm{FB}$ or $40 \mu \mathrm{g}$ of $\mathrm{MBP} / 100 \mu \mathrm{lB}$ or $100 \mu \mathrm{FB}$ (the two latter being controls). The $40 \mu \mathrm{g} \mathrm{MBP} / 100 \mu \mathrm{FB}$ per mouse dose was calculated from the ratio of molecular masses of MBP and the fusion protein (MBP constitutes about $64 \%$ of $\mathrm{MBP} /$ vasostatin). A similar line of reasoning was previously followed by Pike et al. (1998). The therapy was started on the 6th day of the experiment. Both proteins were administered

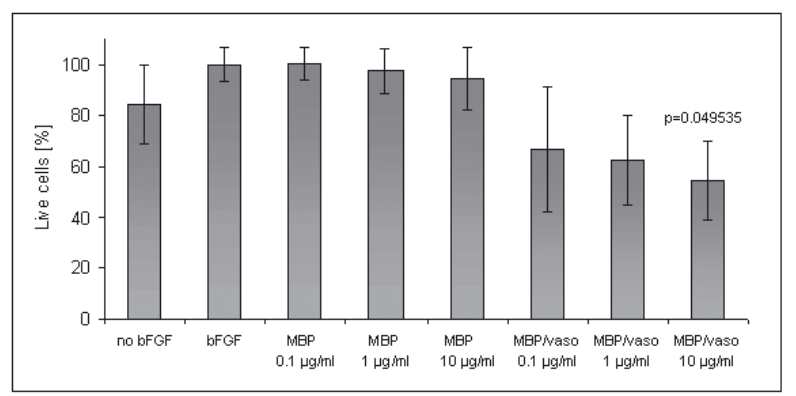

Figure 3. In vitro inhibition of proliferation of endothelial cells.

Endothelial cells (BAEC, $4 \times 10^{3} /$ well) were incubated with bFGF $(25 \mathrm{ng} / \mathrm{ml})$ and various concentrations of proteins: $(0.1-10 \mu \mathrm{g} / \mathrm{ml})$ at $37^{\circ} \mathrm{C}$ for $24 \mathrm{~h}$. Following addition of MTT the percentage of live cells was calculated (see Materials and Methods). The result obtained for $10 \mu \mathrm{g} / \mathrm{ml} \mathrm{MBP} /$ vasostatin group $(P=0.049535)$ is statistically significant as compared to bFGF and $10 \mu \mathrm{g} / \mathrm{ml} \mathrm{MBP}$ control groups (Mann-Whitney $U$-test). 


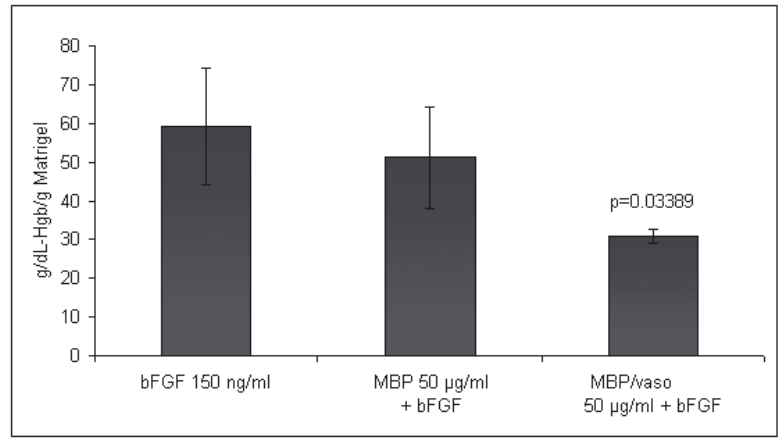

Figure 4. In vivo test of angiogenesis inhibition using Matrigel.

C57B16 female mice (4-week-old) were used. Each group counted 4 animals. Matrigel with bFGF (150 ng/ml) and proteins $(50 \mu \mathrm{g} / \mathrm{ml})$ added was implanted (see Materials and Methods). Hemoglobin content was determined after 7 days. The result obtained for the $\mathrm{MBP} /$ vasostatin group is statistically significant as compared to bFGF $(P=0.03389)$ and MBP $(P=0.03389)$ control groups (Mann-Whitney $U$ test). The experiment was done in duplicate with similar results.

intratumorally for the following 14 days. The results show that $\mathrm{MBP} /$ vasostatin markedly inhibits tumor growth and prolongs survival of treated animals. On the other hand, administration of either MBP or FB solution did not show any therapeutic effect (Fig. 6).

Finally, the MBP/vasostatin therapy was combined with CTX administration (Fig. 7). The chemotherapeutic (170 $\mathrm{mg} / \mathrm{kg}$ body mass) was injected intraperitoneally, every 6 days starting on the 7th day from inoculation, as described by Browder et al. (2000). The fusion protein $(60 \mu \mathrm{g}$ in $100 \mu \mathrm{FB} /$ mouse) was administered intratumorally, starting from the 5th day from inoculation, 5 times a week for 21 days. On the day of CTX administration the mice did not receive injections of the recombinant protein. Inhibition of tumor growth was observed in mice treated with cyclophosphamide, with the fusion protein and with both agents combined. However, the survival of the treated animals was prolonged the most in the combined therapy, as compared to CTX alone $(P=0.01939)$.

\section{DISCUSSION}

Several observations indicate a dependence of invasive tumor growth upon formation of its own network of blood vessels (Folkman, 1971). By inhibiting the process of angiogenesis, also growth suppression of primary tumors as well as metastases is possible (Folkman, 2000). This finding has led to new possibilities in cancer therapy.

This study was aimed at investigating the therapeutic usefulness of a recombinant protein inhibitor of angiogenesis in preventing growth of B16(F10) murine melanoma experimental tumors. In our previous study (Jazowiecka-Rakus et al., 2006), we tested a related therapeutic approach, based on the use of vasostatin gene. The protein approach tested herein has an important advantage of permitting modifications of the therapeutic agent's doses. Since, despite numerous attempts, we were unable to isolate vasostatin devoid of the MBP tag (not shown), we decided to verify the therapeutic usefulness of the $\mathrm{MBP} /$ vasostatin recombinant protein, with MBP alone used as a control.

The recombinant fusion protein obtained here indeed shows antiangiogenic properties. We found that proliferation of endothelial cells (BAEC) was inhibited about $50 \%$ by the fusion protein at $10 \mu \mathrm{g} / \mathrm{ml}$ (Fig. 3). The in vivo test of angiogenesis inhibition using Matrigel established that the studied protein did inhibit formation of new blood vessels stimulated by fibroblast growth factor bFGF present in the Matrigel plug (Fig. 4).

We also determined the therapeutic dose (60 $\mu \mathrm{g}$ of $\mathrm{MBP} /$ vasostatin per mouse) of the antiangiogenic protein causing suppression of B16(F10) murine melanoma tumor growth by at least $80 \%$ (Fig. 5). Repeated administrations (14 times) led to a marked improvement of animal survival (Fig. 6).

The use of the $\mathrm{MBP} /$ vasostatin construct did not lead, however, to complete curing of the animals (Fig. 6). Cessation of drug administration led to regrowth of the tumors. Chronic administration of the antiangiogenic agent could probably arrest the tu-

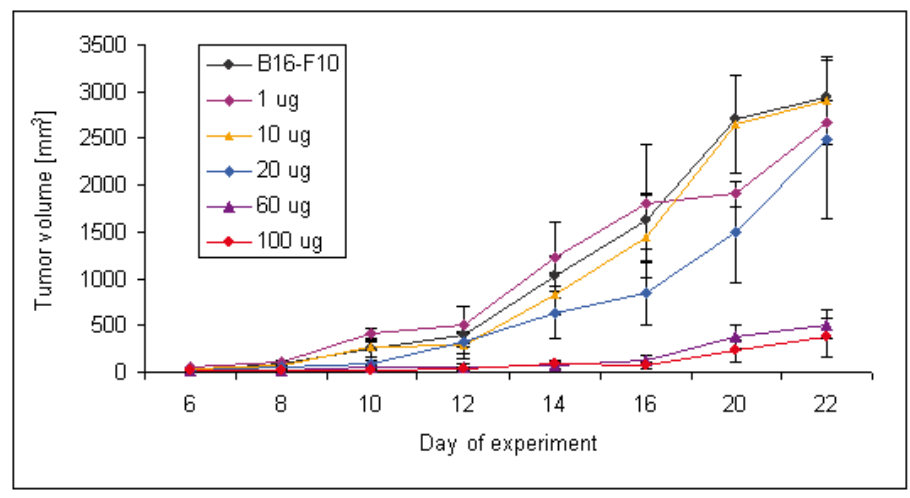

Figure 5. Determining therapeutic dose of $\mathrm{MBP} /$ vasostatin protein that inhibits murine melanoma tumor growth.

Mice were inoculated intradermally with $2 \times 10^{5}$ B16(F10) cells/animal in $100 \mu \mathrm{l}$ PBS $^{-}$and divided into groups of six. Starting from the 6th day from inoculation and continuing daily for 11 days, various doses of $\mathrm{MBP} /$ vasostatin protein: $(1-100 \mu \mathrm{g}$, see graph) in $100 \mu \mathrm{FB} /$ animal were administered intratumorally. Each datapoint represents average tumor volume \pm S.D. For example, on day 16 statistically significant differences were observed between mice from groups receiving $60 \mu \mathrm{g}(P=0.046)$ and $100 \mu \mathrm{g}$ $(P=0.01171)$ of the protein, as compared to the control group (Mann-Whitney $U$-test). 


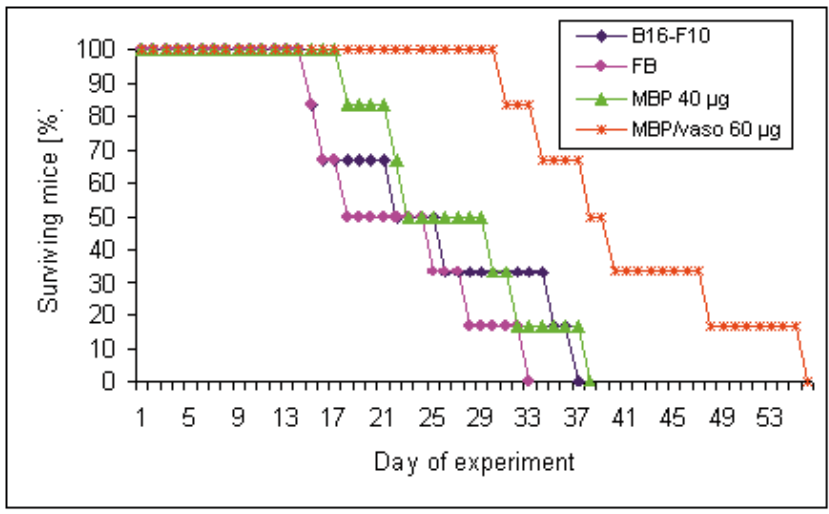

mor growth for the duration of the treatment (Klement et al., 2000).

Further experiments were performed to see if a combined therapy involving administration of $\mathrm{MBP} /$ vasostatin and CTX would lead to improved therapeutic results. According to Browder et al. (2000), CTX administered at an appropriate dose (170 mg/kg body mass, every 6 days) induces, among other effects, apoptosis of endothelial cells lining tumor blood vessels. It turns out that not only low doses of CTX induce an increased expression of thrombospondin-1, an inhibitor of angiogenesis (Hamano et al., 2004), but that CTX has immunostimulatory properties (Loeffler et al., 2005).

A

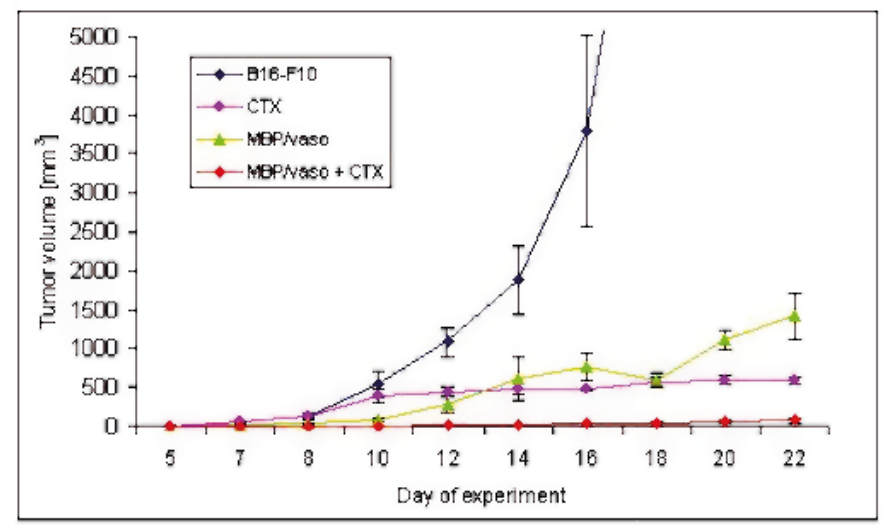

B

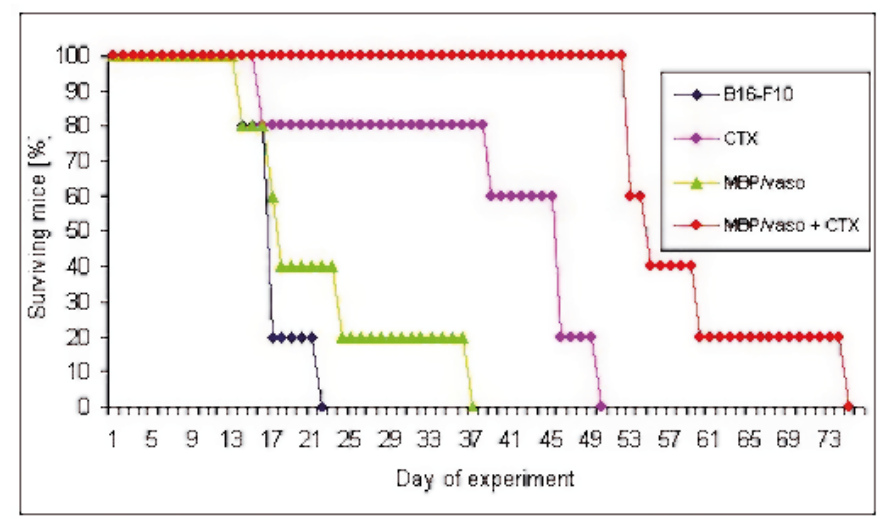

Figure 6. Therapy of mice bearing B16(F10) tumors.

Animals were inoculated intradermally with $2 \times 10^{5}$ $\mathrm{B} 16(\mathrm{~F} 10)$ cells/mouse in $100 \mu \mathrm{PBS}^{-}$and divided into groups of six. The following controls were used: mice receiving $\mathrm{MBP}$ only (40 $\mu \mathrm{g}$ in $100 \mu \mathrm{FB} /$ mouse), mice inoculated with B16(F10) cells only and mice that received FB only $(100 \mu \mathrm{l} /$ mouse). The treated group included mice that were receiving $\mathrm{MBP} /$ vasostatin in $100 \mu \mathrm{FB} /$ mouse. Starting on the 6th day after inoculation, mice from the treated group received recombinant protein daily for subsequent 14 days. The results of survival analysis (logrank test) for the animals treated with the recombinant $\mathrm{MBP} /$ vasostatin protein are statistically significant, as compared to control groups: B16(F10) $(P=0.03734)$, FB $(P=0.01599)$ and $\operatorname{MBP}(P=0.03552)$.

In the combined therapy approach, administration of $\mathrm{MBP} /$ vasostatin $(60 \mu \mathrm{g} / \mathrm{mouse})$ was started five days after inoculation of the animals with cancer cells. The protein was applied five times a week for a total of 21 days. Cyclophosphamide $(170 \mathrm{mg} /$ $\mathrm{kg}$ body mass), on the other hand, was administered intraperitoneally, every six days starting on the 7th day after inoculation. Inhibition of tumor growth and extended survival were indeed clearly observable in mice treated with the combination therapy (Fig. 7).

Application of the recombinant therapeutic protein was started on the 6th day following inoculation, when tumors were $20-30 \mathrm{~mm}^{3}$ in volume

Figure 7. Inhibition of murine melanoma tumor growth by treatment with MBP/vasostatin fusion protein and cyclophosphamide.

A. Inhibition of tumor growth. B. Survival extension. Animals were inoculated intradermally with $2 \times 10^{5}$ B16(F10) cells/mouse in $100 \mu \mathrm{PBS}^{-}$and divided into groups of five. The control group included animals that were only inoculated with neoplastic cells. The following study groups were established: mice receiving $\mathrm{MBP} /$ vasostatin $(60 \mu \mathrm{g}$ in $100 \mu \mathrm{FB} /$ mouse); mice receiving cyclophosphamide alone, and mice undergoing combined therapy. Starting on the 5th day after inoculation, mice received intratumorally the recombinant protein for 21 days (on day 5, 6, 8-12, 14-18, 20-24, 26-29), with the exception of days in which cyclophosphamide was administered. CTX (170 mg/ $\mathrm{kg}$ body mass) was administered on the 7th day after inoculation, and then every six days, i.e. on days 7, 13, 19 and 25. Each datapoint in graph A shows average tumor volume \pm S.D. For example, on day 16 statistically significant differences are seen between the group receiving $\mathrm{MBP} /$ vasostatin plus cyclophosphamide and the controls, including mice inoculated with neoplastic cells only $(P=0.0139)$, mice treated with cyclophosphamide only $(P=0.0135)$, and mice treated with $\mathrm{MBP} /$ vasostatin only $(P=0.0139)$ (Mann-Whitney $U$-test). The results of survival analysis (log-rank test) for the animals treated with recombinant MBP/vasostatin and CTX are statistically significant as compared to control groups: mice inoculated with neoplastic cells only $(P=0.02119)$, mice receiving $\mathrm{MBP} /$ vasostatin only $(P=0.01815)$, and mice receiving CTX only $(P=0.01939)$. 
and must had already developed their microvessel networks. Therefore, our therapeutic approach was aimed at inhibiting the formation of new vessels from the already existing ones.

Several findings have shown that combining various methods of tumor destruction significantly ameliorates the therapeutic effects (e.g., Burke \& DeNardo, 2001; Kerbel \& Kamen, 2004). Especially, chemo- or radiotherapy, when combined with antiangiogenic proteins can markedly improve the therapeutic result (Klement et al., 2000).

One drawback of the protein-based antiangiogenic strategy, besides the necessity of continued drug administration, is its high cost, labor-intensive preparation and purification of the protein, as well as its immunogenicity (Schellekens, 2002). Immunogenic forms of the protein drug may arise during the lengthy production steps and/or during storage as a result of an altered tertiary protein structure caused by aggregation (Meritet et al., 2001).

The therapeutic strategy tested in this study, based on the use of a recombinant antiangiogenic protein combined with cyclophosphamide, markedly inhibited growth of B16(F10) murine melanoma experimental tumors in mice. Such an approach to cancer therapy might be useful in the clinic, especially when attempting to gain growth control of tumors which have already formed microvessel networks.

\section{Acknowledgements}

The study was supported by KBN commissioned grant PBZ-KBN-091/P05/2003.

\section{REFERENCES}

Atreya CD, Singh NK, Nakhasi HL (1995) The Rubella virus RNA binding activity of human calreticulin is localized to the N-terminal domain. J Virol 69: 3848-3851.

Brooks PC, Silletti S, Schalscha TL, Friedlander M, Cheresh DA (1998) Disruption of angiogenesis by PEX, a noncatalytic metalloproteinase fragment with integrin binding activity. Cell 92: 391-400.

Browder T, Butterfield CE, Kraling BM, Shi B, Marshall B, O'Reilly MS, Folkman J (2000) Antiangiogenic scheduling of chemotherapy improves efficacy against experimental drug-resistant cancer. Cancer Res 60: 1878-1886.

Burke PA, DeNardo SJ (2001) Antiangiogenic agents and their promising potential in combined therapy. Crit Rev Oncol Hematol 39: 155-171.

Cao Y (2004) Antiangiogenic cancer therapy. Semin Cancer Biol 14: 139-145.

Chen Q-R, Kumar D, Stass SA, Mixson J (1999) Liposomes complexed to plasmids encoding angiostatin and endostatin inhibit breast cancer in nude mice. Cancer Res 59: 3308-3312.

Folkman J (1971) Tumor angiogenesis: therapeutic implications. $N$ Engl J Med 285: 1182-1186.

Folkman J (2000) Role of angiogenesis in tumor growth and metastasis. Semin Oncol 29: 15-18.
Folkman J (2003) Fundamental concepts of the angiogenic process. Curr Mol Med 3: 643-651.

Gupta SK, Hassel T, Singh JP (1995) A potent inhibitor of endothelial cell proliferation is generated by proteolytic cleavage of the chemokine platelet factor 4. Proc Natl Acad Sci USA 92: 7799-7803.

Hamano Y, Sugimoto H, Soubasakos MA, Kieran M, Olsen BR, Lawler J, Sudhakar A, Kalluri R (2004) Thrombospondin-1 associated with tumor microenvironment contributes to low-dose cyclophosphamide-mediated endothelial cell apoptosis and tumor growth suppression. Cancer Res 64: 1570-1574.

Hanahan D, Folkman J (1996) Patterns and emerging mechanisms of the angiogenic switch during tumorigenesis. Cell 86: 353-364.

Jain RK (2005) Normalization of tumor vasculature: an emerging concept in antiangiogenic therapy. Science 307: 58-62.

Jazowiecka-Rakus J, Jarosz M, Szala S (2006) Combination of vasostatin gene therapy with cyclophosphamide inhibits growth of B16(F10) melanoma tumors. Acta Biochim Polon 53: 199-202.

Kamphaus GD, Colorado PC, Panka DJ, Hopfer H, Ramchandran R, Torre A, Maeshima Y, Mier JW, Sukhatme VP, Kalluri R (2000) Canstatin, a novel martix-derived inhibitor of angiogenesis and tumor growth. J Biol Chem 2: 1209-1215.

Kerbel RS, Kamen B (2004) The anti-angiogenic basis of metronomic chemotherapy. Nat Rev Cancer 4: 423-436.

Klement G, Baruchel S, Rak J, Man S, Clark K, Hicklin DJ, Bohlen P, Kerbel RS (2000) Continuous low-dose therapy with vinblastine and VEGF receptor-2 antibody induces sustained tumor regression without overt toxicity. J Clin Invest 105: R15-R24.

Loeffler M, Kruger JA, Reisfeld RA (2005) Immunostimulatory effects of low-dose cyclophosphamide are controlled by inducible nitric oxide synthase. Cancer Res 65: 5027-5030.

Meritet J-F, Maury C, Tovey MG (2001) Induction of tolerance to recombinant therapeutic protein. J Interferon Cytokine Res 21: 1031-1038.

Michalak M, Milner RE, Burns K, Opas M (1992) Calreticulin. Biochem J 285: 681-692.

Michalak M, Corbett EF, Mesaeli N, Nakamura K, Opas M (1999) Calreticulin: one protein, one gene, many functions. Biochem J 344: 281-292.

Mitrus I, Delić K, Wróbel N, Missol-Kolka E, Szala S (2006) Combination of IL-12 gene therapy and CTX chemotherapy inhibits growth of primary B16(F10) melanoma tumors in mice. Acta Biochim Polon 53: 357-360.

Nyberg P, Xie L, Kalluri R (2005) Endogenous inhibitors of angiogenesis. Cancer Res 65: 3967-3979.

O'Reilly MS, Boehm T, Shing Y, Fukai N, Vasios G, Lane WS, Flynn E, Birkhead JR, Olsen BR, Folkman J (1997) Endostatin: an endogenous inhibitor of angiogenesis and tumor growth. Cell 88: 277-285.

O'Reilly MS, Pirie-Shepherd S, Lane WS, Folkman J (1999) Antiangiogenic activity of the cleaved conformation of the serpin antithrombin. Science 285: 1926-1928.

Papetti M, Herman IM (2002) Mechanisms of normal and tumor-derived angiogenesis. Am J Physiol Cell Physiol 282: C947-C970.

Pike SE, Yao L, Jones KD, Cherney B, Appella E, Sakaguchi K, Nakhasi H, Teruya-Feldstein J, Wirth P, Gupta G, Tosato G (1998) Vasostatin, a calreticulin fragment, inhibits angiogenesis and suppresses tumor growth. $J$ Exp Med 188: 2349-2356.

Pike SE, Yao L, Setsuda J, Jones KD, Cherney B, Appella E, Sakaguchi K, Nakhasi H, Atreya CD, Teruya-Feldstein 
J, Wirth P, Gupta G, Tosato G (1999) Calreticulin and calreticulin fragments are endothelial cell inhibitors that suppress tumor growth. Blood 94: 2461-2468.

Ribatti D, Vacca A (2005) Novel therapeutic approaches targeting vascular endothelial growth factor and its receptors in haematological malignancies. Curr Cancer Drug Targets 5: 573-578.

Scappaticci FA (2002) Mechanisms and future directions for angiogenesis-based cancer therapies. J Clin Oncol 20: 3906-3927.

Schellekens H (2002) Immunogenicity of therapeutic proteins: clinical implications and future prospects. Clin Ther 24: $1720-1740$.

Segers J, Fazio VD, Ansiaux R, Martinive P, Feron O, Wallemacq P, Gallez B (2006) Potentiation of cyclophosphamide chemotherapy using the anti-angiogenic drug thalidomide: importance of optimal scheduling to exploit the 'normalization' window of the tumor vasculature. Cancer Lett 244: 129-135.

Sim BKL, O'Reilly MS, Liang H, Fortier AH, He W, Madsen JW, Lapcevich R, Nacy CA (1997) A recombinant human angiostatin protein inhibits experimental primary and metastatic cancer. Cancer Res 57: 1329-1334.

Wu Z, O'Reilly MS, Folkman J, Shing Y (1997) Suppression of tumor growth with recombinant murine angiostatin. Biochem Biophys Res Commun 236: 651-654.

Wu PC, Yang LC, Kuo HK, Huang CC, Tsai CL, Lin PR, Wu PC, Shin SJ, Tai MH (2005) Inhibition of corneal angiogenesis by local application of vasostatin. Mol Vis 11: 28-35.

Yao L, Pike SE, Setsuda J, Parekh J, Gupta G, Raffeld M, Jaffe ES, Tosato G (2000) Effective targeting of tumor vasculature by the angiogenesis inhibitors vasostatin and interleukin-12. Blood 96: 1900-1905.

Yao L, Pike SE, Pittaluga S, Cherney B, Gupta G, Jaffe ES, Tosato G (2002a) Anti-tumor activities of the angiogenesis inhibitors interferon-inducible protein-10 and the calreticulin fragment vasostatin. Cancer Immunol Immunother 51: 358-366.

Yao L, Pike SE, Tosato G (2002b) Laminin binding to the calreticulin fragment vasostatin regulates endothelial cell function. J Leukoc Biol 71: 47-53. 